\title{
Habitus in the Salt Productions Based People (Study About Mantongan: The Salt Production Workers in Surabaya)
}

\author{
Moch. Imron Rosyidi ${ }^{*}$, Ani Dwi Wimatsari ${ }^{2}$ \\ ${ }^{1}$ Faculty of Communication Science, Universitas Muhammadiyah Magelang, Indonesia \\ ${ }^{2}$ Direktorat Pembangunan Ekonomi Kawasan Perdesaan, Kementerian Desa, Pembangunan Daerah Tertinggal, dan \\ Transmigrasi, Indonesia \\ *Corresponding author. Email: imron.rosyidi@ummgl.ac.id
}

\begin{abstract}
The production of salt-based people still supports most of the national salt needs today, but one of the salt production centers whose existence is threatened is the salt production in Surabaya. The salt production in Surabaya relies on mantongan salt production workers from Madura as the spearhead production. It is because the natives of Surabaya do not want to work in agro complex sectors (agriculture, maritime affairs and fisheries, and livestock). It causes the natural conversion, because it is considered as the thing without economy impact. Therefore, its existence is threatened. This research aims to describes the formation of habitus so it creates the social practice of the the relationship between boss and mantongan. The method which will be used is qualitative method by critical explanative approach. Whereas the theory used is Pierre Bourdieu's social practice about habitus and the arena of cultural production. The result of this research is the arena of salt production still shows the tendency of symbolic power. Habitus in salt-based people production is still formed by Doxa and mantongans have no power. They need the boss' help. Bordieus's concept about the Heterodoxa relationship usually happens in the low structure condition, contrary to the social condition of the mantongan community. The relationship between the boss and mantongan has not worked fairly and it shows the tendency of symbolic power from stereotype formed.
\end{abstract}

Keywords: habitus, critical studies, symbolic powers

\section{INTRODUCTION}

Based on data from the Ministry of Maritime Affairs and Fisheries, the annual national salt demand is around 3.2 million tons, of which People's Salt Production reaches 2.5 million tons with shrinking $25 \%$ remaining around 1.8 million tons [1]. East Java Province in 2017 still accounts for around $12 \%$ of national salt needs. One area in East Java Province which is the center of the People's Salt Production is the City of Surabaya, which is the result of bay salt (Garam Rosok; in Javanese) which is currently able to produce $5 \%$ of the total East Java people's salt business or 20,000 tons of a total of around 400,000 tons of salt produced in 2017 [2]. This data shows that at present the city of Surabaya can still be productive and contribute to national salt production.

People's Salt Production in Surabaya, especially in West Surabaya, is generally not produced by indigenous people of the area. Instead, it uses labor, and in the harvest period, uses a profit-sharing system between the skippers and salt production workers from ethnic Madurese community. The salt production workers here are called Mantongan, the term for the skippers s of seasonal salt fields. Derived from the word Mantong which means salt fields and Mantongan means the skippers s of salt fields. This labeling is based on their social status and has been going on for a long time.
In the study of communication, the process of communication between mantongan and Skippers is very interesting and is likely to greatly influence the activities of salt production itself. But if we look deeper, there is a kind of injustice in the profit-sharing process because the the skippers seem to be exploited by mantongan's energy. Not to mention the initial susbidi bond money for living expenses make mantongan're losing bargaining power in the deal.

This phenomenon in some agricultural studies is often referred to as the SAKAP system. The SAKAP system is a system of agreement for the outcome between financiers and peasants [3]. In this system there are several mechanisms, Maro (for two 1:1), Morotelu (for three 1:2), and Moropapat (for four 1:3). In the case of the Mantongan and the Skippers implemented the Morotelu system (for three 1:2). The results were deducted again the cost of living loans during the production of salt from 300,000 to 600,000 Rupiah every week. With such income the Mantongan people even many are living as scavenger. They become a scavenger to meet the needs of his life [4], because their location is very close to TPA in West Surabaya.

The ambition which is the ethnic Madurese community by the local community is that they get a lot of bad stereotypes. Like many Javanese people, native residents of West Surabaya, often cannot distinguish mantongan from scavengers. Although a small portion of the mantongan that is surrounded around the Benowo landfill does indeed have 
a side job as a scavenger. the mantongan that works as a scavenger on the side is described in the Desertation of the Scavenger Livelihood Strategy in Maintaining Survival in the Njawar Final Disposal Site (TPA) in Pakal City, Surabaya [5].

In practice the indigenous people around Pakal District and Benowo Subdistrict refer to scavengers as Wong Mantongan. Many of the Benowo people in Surabaya use mantongan as a warning subject for their children not to play far from home. The fear that is channeled to their children is, when they play far away, they can be kidnapped by 'Mantongan. 'Ojo dolan adoh-adoh' (Don't Play so far), is not called by Mantongans (scavenger) or not for child due. Mantongan' in this case is not the true to be meaning, but the mantongans connoted with scavengers. So that the label mantongan as a salt production worker has been biased to become scavengers, scavengers that need to be aware of their existence. Then to explain the phenomenon. The researcher formulated a research problem how is the phenomenon of symbolic resistance due to Skippers's intervention in Mantongans at the people's salt production arena? with the aim of explaining how habitus about Mantongans to construct in the salt production, is seen from the perspective of the cultural production arena.

\section{LITERATURE REVIEW}

\subsection{Pierre Bourdieu's social practice}

The theory that will be used in this research is Pierre Bourdieu's Social Practice Practice consists of synergy between habitus, capital and the arena. The concept of Bourdieu's simplest social practice can be understood to consist of Habitus x Capital and Arena (Field) = Practice. This series, namely the concept - Habitus, Capital and Arena - can help with theorizing the choice of maintaining salt production [6].

a. Habitus is a special feature, whether knowledge, attitudes, habits, even physical traits that are formed through the experience and interaction of individuals or groups for a long time in a community so that it can exist in a particular field [7], in this case: knowledge will season and climatic conditions. Attitudes towards the environment and the salt market, Negotiating habits mantongan in the production of salt. Even certain physical characteristics such as black skin and strong bodies commonly possessed by actors, in the field of salt production.

b. Capital refers to the type of actor's resources that are carried in social interactions or others for products of interaction. Consists of Economic Capital, Social Capital, Symbolic Capital, Cultural Capital [8].

1) Economic Capital which shows materialist sources such as salt land and money.

2) Social Capital is a resource related to 'network ownership, mutual acquaintance, and recognition' in the field of salt production.

3) Symbolic capital that is associated with labels and stereotypes, such as the mention of Mantongan.
4) Cultural Capital in the form of institutionalized skills and knowledge and so on.

c. Arena or field also refers to social space (such as the academic field or health field), but also in the form of configuration or network of relationships with certain distributions such as power, in this research Arena is an existing Field of Production of People's Salt [9]. In the Arena there is Doxa which is a set of fundamental beliefs that exist in the production of people's salt in Bourdieu's short sentence; the universe of the undiscussed or "universe that is not discussed"[10]. In addition there is Orthodoxa referring to situations in which doxa is recognized and accepted in practice, the dominant group that has the power to try to maintain the structure it dominates by producing orthodoxy in people's salt production. In a weak structure, Heterodoxa is a thought or idea that is explicitly conveyed which questions the legitimacy of perceptions and appreciation schemes that are being applied in an Arena or the field of production of people's salt [6].

\subsection{Communication perspective group between intercultural working groups}

The practice that will be taken in this is the practice of Communication Group John Oetzel [11]. Communication of the group is group communication in the perspective of work groups in an intercultural perspective. Where in a group there are cultural differences in its members such as ethnicity, religion, nationality, gender, language, and so on. In that difference the most important according to Oetzel are: 1. Individualism- collectivism, 2. Self-understanding, 3. Face problems or images.

\section{METHOD}

In this study, qualitative methods used to criminalize a phenomenon occurring in the people's salt production. The preferred approach is a critical study approach through data analysis with reduction analysis techniques. Researchers choose to use this approach as researchers want to see, uncover and uncover events in terms of people's salt production in Surabaya. Some qualitative research is feared to be difficult to separate alignments and Objectivity, if the researcher is already an insider of the community. In this study a critical tradition that has alignments and stems to the empowerment of society [12] is considered the most comprehensive to answer the objectives in this study. This research informant is chosen in Purposif, with criterion is the perpetrator of salt production of people consist of Mantongan and skippers. 


\section{RESULT AND DISCUSSION}

\subsection{Communication as practice perspective group between intercultural working}

Group communication that occurs is very different between what happens in the telon and paron systems.

Table 1 Comparison communications group system paron and telon

\begin{tabular}{|c|c|c|c|}
\hline No & Concepts & System Telon & System Paron \\
\hline 1. & $\begin{array}{l}\text { Element to } \\
\text { Forming } \\
\text { communication } \\
\text { groups }\end{array}$ & $\begin{array}{l}\text { Shape is } \\
\text { secondary }\end{array}$ & $\begin{array}{l}\text { It is up to the } \\
\text { primary forming }\end{array}$ \\
\hline 2. & $\begin{array}{l}\text { Culture of } \\
\text { individualism- } \\
\text { collectivism }\end{array}$ & $\begin{array}{l}\text { Skipers } \\
\text { individualism } \\
\text { while the } \\
\text { mantongan } \\
\text { collectivism }\end{array}$ & $\begin{array}{l}\text { Between } \\
\text { mantongan and } \\
\text { skippers a like } \\
\text { individualism, }\end{array}$ \\
\hline 3. & $\begin{array}{l}\text { Self construal / } \\
\text { pemaaman } \\
\text { themselves }\end{array}$ & $\begin{array}{l}\text { Squire } \\
\text { independent } \\
\text { Meanwhile, Spells } \\
\text { interdependent }\end{array}$ & $\begin{array}{l}\text { Between } \\
\text { mantongan and } \\
\text { skippers are } \\
\text { Interdependent }\end{array}$ \\
\hline 4. & Image & $\begin{array}{l}\text { Mantongan } \\
\text { communicates } \\
\text { with other faces }\end{array}$ & $\begin{array}{l}\text { Mantongan } \\
\text { communicates } \\
\text { with Mutual face }\end{array}$ \\
\hline 5. & $\begin{array}{l}\text { Degrees of } \\
\text { Communication }\end{array}$ & $\begin{array}{l}\text { Degrees have not } \\
\text { Equal }\end{array}$ & Degrees Equal \\
\hline
\end{tabular}

Communication that occurs is communication that still touches the interests of individuals caused by these interventions. In the perspective of the intercultural working group the model is more on collectivism, but more adheres to what the boss said. In this case the skippers are still individualism. This is possible due to the culture that has been formed for quite a long time so that in the culture of intervened collectivism communication there is no equal degree. In some cases, it is still possible for mutual understanding, where mutual understanding in the intercultural work perspective does not necessarily reach Equal degree.

In communication practice, the Self Constraint is still independent so it is difficult to communicate. Although in terms of language the mantongan and skippers claimed not to be constrained. Individual cultures tend to emphasize that they are independent, more concerned with self-interest than group interests. For example, when in the individual cultural category see other members talking, he will see him speaking as an individual not as a group. On the other hand, Culture of collectivism tends to prioritize group interests rather than their own individual interests. They consider themselves part of a group so they tend to avoid talking that is unpleasant or sensitive. System Telon applied tend to form Individualistic Culture, resulting in communication is limited to meeting the needs of individuals.

\subsection{Resistance in habitus}

Bourdieu explains that in each strong structure there is Doxa in the form of culture formed or forming the structure.
Which if realized in practice becomes Orthodoxy which can no longer be changed, in Bourdieu's language 'universe is not discussed' [10]. However, when the weakened structure raises consciousness to be free from the bonds of doctrine, this is called Heterodox.

Oppression of mantongan like the opinion above, is a consequence of stereotypes formed by local culture. Mantongan is identified with the lower classes and thieves. So that the behavior of such discrimination is considered reasonable by the skippers. They are very worried about the bad actions of the mantongan who are of ethnic Madurese origin, thus giving rise to bad prejudices against them as in the discussion in chapter four.

Conflicts that do not surface can lead to other conflicts that will one day explode on a large scale. The conflict SampitMadura in the 2000s also began with small individual conflicts and widened into even ethnic group conflicts [13]. Madurese with their hard culture actually do not want to be discriminated against in such a way, but economic conditions force them to remain submissive behind the skippers.

In a story of an informant, a skipper whom they were unable to drive, they responded to acts of violence. The violence was in the form of cutting or damaging tarps or geomembranes which cost up to 8 million rupiah per plot. This is the nadir point of that who are no longer able to survive with the boss's behavior are considered outrageous for them.

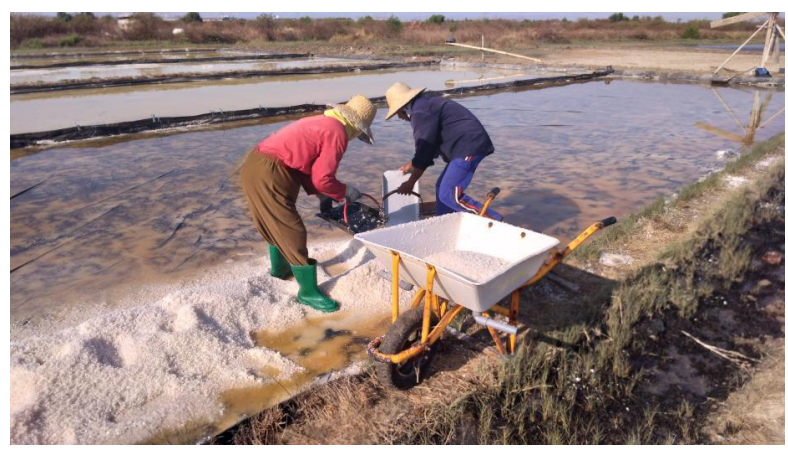

Figure 1 Mantongan harvesting salt on the geomembrane

On the other hand, skippers' unfavorable image in the eyes of mantongan it difficult for the skippers itself. This is because there are no helpers who want to work on their fields. Finally, many fields are rented to other skippers. If all the mantongan in Surabaya thinks so then it is not impossible for salt production in Surabaya to be threatened with its existence.

(07/07/18, Juwito)

Yeah, like, the Hajj *** is awkward, sometimes it's already been there, the incentive, sometimes there is a tarpaulin (geomembrane), directly using the sickle, it's damaged in the same way, it's too much.

(07/13/18 Buhara).

Immediately given it was delicious. But if it is still complicated, no one will want to come along, trouble. If indeed Mantongan is already emotional. Yes, I don't know, 
it's for example tearing off the tarp. Geomembrane. Already memorize lazy come along again.

\section{(07/13/18 Buhara)}

Nobody wants to work (land of Hajj ***) He is very distance from subordinates. The rules are hard too. Difficult to take (middle ground) to win alone. He thinks Mantongan is like a toy.

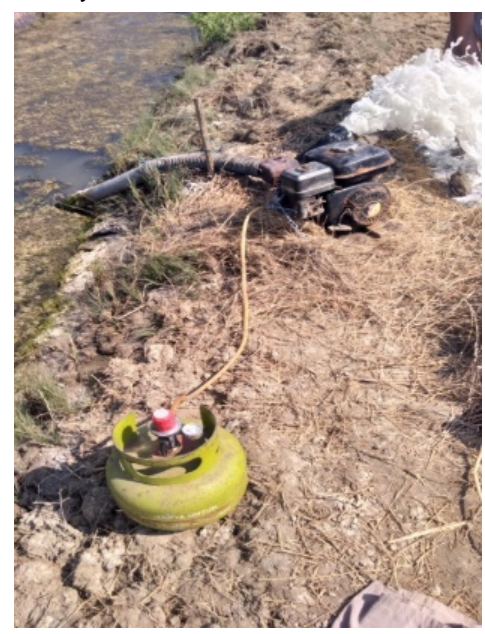

Figure 2 Mantongan used LPG to diversification fuel diesel
Conflict to cutting geomembranes cost tens of millions of rupiah, and there is no guarantee those that who want to work on their land are things that the skippers never wanted. The owner of capital has a very central role and position in this production. However, in practice the welfare mantongan as the spearhead of salt production is very noteworthy.

Contrary to Bourdieu's concept that Heterodox can be achieved when conditions of social structure weaken. In the practice of group communication in the production of salt, it is precisely when the skippers show his symbolic power by suppressing the incantation, so that he can resist implicitly. The concept of doxa and orthodox here is no longer valid when society is at its nadir. When the structure strengthens and the agent is at its weakest point, it allows the agent to carry out heterodox or symbolic resistance to the agent who controls the structure.

The concept of doxa in salt production is in the form of affirmation of the symbolic power that mantongan has no power and is in dire need of a helping hand from skippers. In the orthodox concept of salt production, it is really a labor tool that falls into symbolic power. The Heterodoxa in the limit point equity, a rise when the mantongan community's stuck in the weakest structure and the boss is in the strongest condition in the context of capital control and production applications. The accumulation of all of this is the awareness of resistance to fight and aware of their position as the spearhead of the production of people's salt in Surabaya.

Table 2 Habitus in people's salt production in Surabaya

\begin{tabular}{|c|c|c|}
\hline No & Aspects of & Conditions / Problems \\
\hline 1 & Aspects of Knowledge about Salt & $\begin{array}{l}\text { a. Marts are owned by mantongan. } \\
\text { b. It has become a habbit for mantongan }\end{array}$ \\
\hline 2 & Attitude about the management aspects of salt & $\begin{array}{l}\text { a. Mantongan adapt to the local culture (Using Google Weather, use windmills and diesel) } \\
\text { b. Mantongan innovate ataas diesel fuel scarcity }\end{array}$ \\
\hline 3 & Aspect negotiate habits & $\begin{array}{l}\text { a. Following economic needs, the relationships formed by Patron-client system } \\
\text { b. Many use the system telon }\end{array}$ \\
\hline 4 & Doxa & It is an affirmation of symbolic power that the mantongan does not have power \\
\hline 5 & Heterodox & In conditions of a strong structure latent \\
\hline
\end{tabular}

\section{CONCLUSION}

In the creation of social practice, the concept of Bourdieu on the Heterodox is broken with the phenomenon of the mantongan resistance of social capital. They are nadir capable of forming a conception of resistance, resulting in one of the skippers cannot be produced this year. This is the case in the middle relationship of strong and dominated structures. Thus, Bourdieu concept of a common heterodoctoral relationship occurs in a weakened structure, contrary to the social condition of the poor community, where they are a weak group in the strong structure.

The relationship of the skippers and Mantongan that has not been fair, and still shows the tendency of symbolic power of the many stereotypes formed. Heterodoxas have indeed formed on several Mantongan, but are still implicitly, so they have not dared to have a blatantly resistance.

The group communication practice of the relationship between the skippers and the Mantongan system of Telon also has not been able to create a new space effective in paron system.

\section{ACKNOWLEDGMENT}

Thank you for saying to Prof. Partini as Bourdieu's theorist for advice in this study. In addition, thanks I also give Mr. Asc. Prof. Subejo about the concept of Paron in the farm, that opens a new discourse for me, in first time researching the field of agriculture.

\section{REFERENCES}

[1] K. Kelautan, "Perikanan (KKP). 2015," Kelaut. dan Perikan. dalam angka, 2010. 
[8] F. M. Collyer, K. F. Willis, M. Franklin, K. Harley, and S. D. Short, "Healthcare choice: Bourdieu's capital, habitus and field," Curr. Sociol., vol. 63, no. 5, pp. 685-699, 2015.

[9] G. Ritzer and J. Stepnisky, Modern sociological theory. SAGE Publications, 2017.

[10] M. Grenfell, "Bourdieu in the field: From the Béarn and to Algeria - A timely response," French Cult. Stud., vol. 17, no. 2, pp. 223-239, 2006.

[11] A. C. W. Morissan and F. Hamid, "Teori komunikasi massa," Ghalia Indones. Jakarta. Morissan,(2013). Teor. Komun. Individu Hingga Massa. Kencana Prenada Media Group. Jakarta, 2010.

[12] L. W. Neuman, Social Research Methods, 6/E. Pearson Education India, 2007.

[13] M. I. Rosyidi, "Komunikasi Kelompok Dalam Pemberdayaan Masyarakat Kampung Kelbung Pasca Konflik Madura-Sampit.," J. Komun., vol. 12, no. 1, pp. 51-62, 2018. Elem. Teor. Syst. Naucz., vol. 2, 2006.

[6] N. Krisdinanto, "Pierre Bourdieu, Sang Juru
Damai," KANAL J. Ilmu Komun., vol. 2, no. 2, pp.
189-206, 2016. 189-206, 2016.

[7] P. Bourdieu and J.-C. Passeron, "Reprodukcja,"

[2] S. T. Ardiyanti, "Produksi Garam Indonesia," Info [5] M. Ita Kusuma, S. S. Hariadi, and M. Subejo, "The Disposal In Njawar, Benowo, Surabaya, Indonesia," 2016.

\author{
Elem. Teor. Syst. Naucz, vol. 2, 2006.
}

